\title{
Pengelompokan Berita Indonesia Berdasarkan Histogram Kata Menggunakan Self-Organizing Map
}

\author{
Ambarwati*1 $^{1}$, Edi Winarko ${ }^{2}$ \\ ${ }^{1}$ Jurusan Teknik Komputer, Instituto Profissional de Canossa, Dili \\ ${ }^{2}$ Jurusan Ilmu Komputer dan Elektronika, FMIPA UGM, Yogyakarta \\ e-mail: *11 kristiyani.ambarwati@yahoo.com, ${ }^{2}$ ewinarko@gmail.com
}

\begin{abstract}
Abstrak
Berita merupakan sumber informasi yang dinantikan oleh manusia setiap harinya. Manusia membaca berita dengan kategori yang diinginkan. Jika komputer mampu mengelompokkan berita secara otomatis maka tentunya manusia akan lebih mudah membaca berita sesuai dengan kategori yang diinginkan. Pengelompokan berita yang berupa artikel secara otomatis sangatlah menarik karena mengorganisir artikel berita secara manual membutuhkan waktu dan biaya yang tidak sedikit.

Tujuan penelitian ini adalah membuat sistem aplikasi untuk pengelompokkan artikel berita dengan menggunakan algoritma Self Organizing Map. Artikel berita digunakan sebagai input data. Kemudian sistem melakukan pemrosesan data untuk dikelompokkan. Proses yang dilakukan sistem meliputi preprocessing, feature extraction, clustering dan visualize. Sistem yang dikembangkan mampu menampilkan hasil clustering dengan algoritma Self Organizing Map dan memberikan visualisasi dengan smoothed data histograms berupa island map dari artikel berita. Selain itu sistem dapat menampilkan koleksi dokumen dari lima kategori berita yang ada pada tiap tahunnya dan banyaknya kata (histogram kata) yang sering muncul pada tiap arikel berita. Pengujian dari sistem ini dengan memasukan artikel berita, kemudian sistem memprosesnya dan mampu memberikan hasil cluster dari artikel berita yang dimasukan.
\end{abstract}

Kata kunci-Pengelompokkan berita Indonesia, pengelompokkan berdasar histogram kata, pengelompokan berita menggunakan SOM

\begin{abstract}
News is awaited information resources by humans every day. Human reading the news with the desired category. If the computer able to news clustering with automatically, humans of course will be easier to read the news according to the desired category. News clustering in the form of news articles with automatically very interesting because it organizes news articles manually takes time and costs not a little bit.

The purpose of this research is to create a system application for grouping news articles by using the Self Organizing Map algorithm. News article be used as input into the system. News articles used as input data. Then the system performs data processing until to be clustered. Processes performed by the system covers: preprocessing, feature extraction, clustering and visualize. The system developed is able to display the results clustering of the Self Organizing Map algorithm and gives visualization of the Smoothed Data Histograms in the form of island map from news articles. Additionally the system can display a word histogram and news articles from five categories news in each year. Testing of this system by entering the news articles, then the system performs data processing and gives results of a cluster from news articles that input.
\end{abstract}

Keywords - Indonesia news clustering, clustering based on words histograms, news clustering using SOM

Received December $1^{\text {st }}$,2013; Revised January $1^{\text {st }}$, 2013; Accepted January 15 ${ }^{\text {th }}, 2014$ 


\section{PENDAHULUAN}

$\mathrm{J}$ umlah sumber berita berbahasa Indonesia yang tersedia di internet semakin besar [1] apalagi berita dalam jumlah besar setiap harinya. Pengelompokkan berita yang berupa artikel secara otomatis sangatlah menarik karena mengorganisir artikel secara manual akan menjadi sangat mahal [2] atau tidak dapat dikerjakan dengan mudah karena keterbatasan waktu dari jumlah dokumen yang digunakan. Artikel dapat dikelompokkan dengan membagi artikel berita ke dalam kategori berita yang telah ditentukan sebelumnya. Setiap kategori berita mempunyai kemiripan isi berita yang yang tentunya bisa divisualisasikan dengan cluster.

Clustering dapat digunakan untuk membantu menganalisis berita dengan mengelompokkan secara otomatis berita yang memiliki kesamaan [3] isi. Clustering adalah aktifitas pengelompokkan berita tanpa supervisi ke dalam clusters. Masalah mendasar dalam clustering artikel berita adalah mengelompokkan artikel berita yang mempunyai kemiripan isi diantara artikel berita satu dengan artikel berita yang lain [4]. Salah satu algoritma yang bisa digunakan untuk menyelesaikan clustering adalah algoritma SOM Kohonen. [5] mengemukakan bahwa koleksi dokumen yang besar dapat disusun sesuai dengan kesamaan tekstual dan statistik representasi dari isi tekstual digunakan sebagai fitur vektor dokumen dengan algoritma SelfOrganizing Map (SOM).

Dalam penelitian [6] yang dikembangkan ini menggunakan algoritma Dynamic Time Warping (DTW) untuk mencocokan kurva linier dengan membandingkan gaya tulisan tangan dan SOM dipakai sebagai algoritma dalam pembentukan cluster. Algoritma SOM melakukan pemetaan nonlinear yang memelihara topologi lokal properti dari kumpulan database tulisan tangan tersebut. Hasilnya adalah menemukan bentuk gaya penulisan tangan dan dapat mengelompokan tulisan tangan tersebut secara otomatis dengan sistem yang dibangun. Penelitian [7] mengenai pengintegrasian sistem Bveritas dan mengatur artikel berita pada situssitus berita berbahasa Inggris. Sistem mengatur berita secara otomatis dari beberapa situs berita menggunakan menggunakan Self-Organizing Map (SOM). Pengelompokan dokumen didasarkan pada distribusi frekuensi dari kata-kata yang digunakan pada artikel berita tersebut. Sistem yang dibangun menyediakan topik dan kategorisasi regional dengan kombinasi headlines dan breaking news. Sistem juga menyediakan layanan yang bermanfaat seperti ringkasan berita dimana seorang pengguna dapat memilih tingkat ringkasan berita yang diinginkan pada suatu artikel berita. Penelitian [1] mengenai clustering untuk corpus berita berbahasa Indonesia. Penelitian ini menggunakan metode pembobotan log-tf (logarithmic term frequency) dan logtf.idf (logarithmic term frequency - inverse document frequency). Algoritma yang digunakan dalam clustering yaitu algoritma K-Means. Sistem yang dibuat mampu menghasilkan clustering berita dapat digunakan untuk mencari berita yang terkait, mencari kategori baru dan memperlihatkan keterkaitan antara berita.

\section{METODE PENELITIAN}

SOM merupakan metode pengelompokan yang menyediakan penataan kelas-kelas berdasarkan topologinya. SOM dilatih secara iteratif melalui sejumlah epoch. Sebuah epoch didefinisikan sebagai proses dari semua pola input sehingga masing-masing pola input akan diproses sebanyak jumlah epoch [8]. SOM adalah jaringan saraf single layer dimana neuron ditetapkan sepanjang grid n-dimensi [8]. Jaringan SOM Kohonen terdiri dari dua lapisan (layer), yaitu lapisan input dan lapisan output. Setiap output neuron menerima input melalui bobot yang terhubung dengan masukan, sehingga vektor bobot memiliki dimensi yang sama dengan vektor input.

Awalnya algoritma SOM melakukan inisialisasi berupa bobot $\left(\mathrm{w}_{i j}\right)$ yang diperoleh secara acak untuk tiap node. Setelah bobot $\left(\mathrm{w}_{i j}\right)$ diberikan maka jaringan diberikan input $\left(x_{i}\right)$. Setelah input diterima jaringan akan melakukan perhitungan jarak vector $D(j)$ yang didapat dengan menjumlahkan selisih antara vector bobot $\left(\mathrm{w}_{i j}\right)$ dengan vector input $\left(x_{i}\right)$.

IJCCS Vol. 8, No. 1, January 2014 : $101-110$ 
$D(j)=\sum_{i}\left(w_{i j}-x_{i}\right)^{2}$

Setelah jarak atara node diketahui maka ditentukan nilai minimum dari perhitungan jarak vector $D(j)$, maka tahap selanjutnya melakukan perubahan bobot $w_{i j}($ new $)$.

$$
w_{i j}(\text { new })=w_{i j}(\text { old })+\alpha\left[x_{i}-w_{i j}(\text { old })\right]
$$

Pada proses untuk mendapatkan bobot baru memerlukan nilai learning rate $(\alpha)$ yaitu 0 $\leq \alpha \leq 1$. Nilai learning rate pada setiap epoch akan berkurang menjadi $\alpha_{(i+1)}=0.5 \alpha$ [8]. Kondisi penghentian pengujian dilakukan dengan menghitung selisih antara bobot $w_{i j}$ (new) dengan $w_{i j}$ (old), apabila nilai $w_{i j}$ hanya berubah sedikit saja, berarti pengujian sudah mencapai konvergensi sehingga dapat dihentikan [9].

\subsection{Analisa}

Penelitian ini membahas masalah clustering pada artikel berita Indonesia yang diambil dari majalah Tempo. Diperlukan tahapan-tahapan yang harus dilakukan untuk mendapatkan cluster dari artikel berita tersebut. Tahapan-tahapan yang harus dilakukan adalah preprocessing, feature extraction, clustering dan visualisasi.

\subsubsection{Preprocessing}

Preprocessing merupakan tahap awal yang dilakukan untuk meningkatkan kualitas dari data. Sebelum proses preprocessing dilakukan, perlu disiapkan artikel berita yang akan diproses dalam bentuk file teks dan disimpan. Metodologi yang dilakukan dalam preprocessing yaitu tokenization, stopword removing dan stemming.

Proses yang terjadi dalam tokenization dalam penelitian ini sebagai berikut: artikel berita akan diproses dengan menjadikan semua huruf besar (capital) menjadi huruf kecil (lower case) proses ini dinamakan case folding. Kemudian sistem akan melakukan langkah untuk memisahkan deretan kata di dalam kalimat, paragraf atau halaman menjadi token atau potongan kata tunggal. Apabila terdapat deretan angka pada artikel sistem akan menghapusnya secara otomatis.

Pada stopwords removing system akan mencocokan kata hasil dari proses tokenization dengan kata-kata yang terdapat dalam kamus stopwords yang telah dibuat, jika terdapat kata yang sama maka kata itu akan dihapus.

Stemming akan memproses kata tersebut satu persatu. Proses ini akan mengecek kata hasil dari stopwords dan membandingkannya dengan kamus kata dasar (rootwords) jika ditemukan sama maka kata tersebut akan disimpan. Apabila kata yang dicocokan tidak diketemukan dalam kamus kata dasar maka akan sistem akan mengenali sebagai kata turunan. Kemudian sistem akan mengubah kata turunan menjadi kata dasar menggunakan algoritma Nazief \& Adriani.

\subsubsection{Feature Extraction}

Feature extraction merupakan proses untuk menciptakan feature vector yang menggambarkan isi dari data. Feature extraction pada sistem ini memanfaatkan package SOMLib. Pada sistem yang dibangun proses yang dilakukan dalam feature extraction memerlukan 4 class yang ada dalam package SOMLib, yaitu: wordsexc, templatevectorexc, reducerexc dan extractorexc.

Pada class wordsexc, langkah-langkah yang dilakukan antara lain: menetapkan nilai minimum dari panjang kata dan menterjemahkan artikel berita ( hasil dari proses stemming ) ke dalam file histogram. Hasil dari proses dari class wordsexc adalah suatu hashtable berisi informasi yang mungkin mewakili kata-kata tunggal dan jumlah pemunculan kata. Class templatevectorexc berfungsi untuk menterjemahkan file histogram kedalam template vector dengan menggabungkan file-file yang dibuat pada proses wordhistogram menjadi sebuah file tunggal dan membuat pengindeksan dari artikel berita secara lengkap. Class reducerexc berfungsi untuk menetapkan minimum dan maksimum pemunculan dari sebuah kata, dengan 
nilai antara 0 dan 1 serta menghapus kata yang mempunyai pemunculan sedikit. Class extractorexc mengunakan pembobotan term frequency (tf) yang dikalikan dengan inverse document frequency (idf). Artikel berita direpresentasikan dengan matriks term-frequency yang mempunyai nilai antara 1 dan 0 . Nilai nol berarti bahwa term tersebut tidak hadir di dalam dokumen. Setiap sel dalam matriks bersesuaian dengan bobot yang diberikan dari suatu term dalam dokumen yang ditentukan

\subsubsection{Clustering}

Clustering pada penelitian ini menggunakan SOMTolbox untuk mendapatkan hasil cluster. Pembentukan cluster dimulai dengan memberikan input file vector dari feature extraction dan menkonversi format data tersebut dengan method som_data_struct(Array) untuk membuat struktur data SOM dengan format file mat. Untuk mendapatkan file mat yang akan digunakan untuk proses SOM cluster. Melakukan proses normalisasi, dimana normalisasi digunakan untuk menormalkan vektor dokumen. Kemudian system akan membuat cluster dengan metode Self Organizing Map.

Parameter yang dibutuhkan dalam proses clustering: Lapisan input berupa matriks 2 dimensi berukuran XDIM x VEC_DIM, XDIM adalah jumlah data dan VEC_DIM adalah jumlah dimensi data sesuai dengan hasil feature extraction. Lapisan output berupa matriks 2 dimensi berukuran YDIM x VEC_DIM, YDIM adalah jumlah map unit dan VEC_DIM adalah jumlah dimensi data sesuai dengan hasil feature extraction. Menggunakan topologi hexagonal.

Pada proses SOM cluster ini sistem akan memanggil fungsi-fungsi yang terdapat dalam SOMTolbox yaitu fungsi som_randinit, som_batchtrain dan som_autolabel. Adapun langkahlangkah yang dilakukan antara lain: Inisialisasi awal dengan som_randinit. Training yang dilakukan menggunakan som_batchtrain. Proses pelabelan dilakukan dengan menggunakan som_autolabel.

\subsubsection{Visualisasi}

SOM visualize menggunakan SDHToolbox untuk memperoleh bentuk visualisasinya. SOM visualize merupakan suatu proses untuk menampilkan bentuk cluster seperti gugusan pulau-pulau (islands). Adapun langkah-langkah yang dilakukan antara lain:

a. Melakukan perhitungan nilai penyebaran vektor dengan fungsi sdh_calculate.

b. Menampilkan visualisasi hasil clustering berupa island dari Smoothed Data Histogram menggunakan fungsi sdh_visualize.

Method yang digunakan untuk menghitung smoothened data histogram yaitu sdh_calculate(sData:SOM, sMap:SOM). Setelah selesai dihitung sistem akan menampilkan kluster-kluster ke dalam model islands dengan method sdh_visualize(islands:SDH).

\subsection{Arsitektur Sistem}

Alur proses yang dilakukan oleh seorang pengguna digambarkan dalam bentuk diagram sistem seperti terlihat pada Gambar 1. Sistem yang dibuat dalam penelitian ini terdiri dari input, proses dan output. Input yang dipakai dalam penelitian ini berupa file teks yang akan diinputkan oleh user pada waktu akan memulai proses. Proses yang terjadi dalam sistem ini meliputi preprocessing, feature extraction, clustering dan visualisasi. Hasil yang didapat berupa tabel yang berisi pengurangan kata, kata dasar dari hasil preprocessing, cluster dari artikel berita dan informasi mengenai jumlah daftar kata terbanyak yang ditampilakan dengan 10 urutan kata. Pada arsitektur sistem ini terdapat 2 kamus data yaitu kamus data yang berisi kata-kata (stopwords) yang akan dibuang dan kamus kata dasar (rootwords) yang digunakan untuk mencocokan kata. 


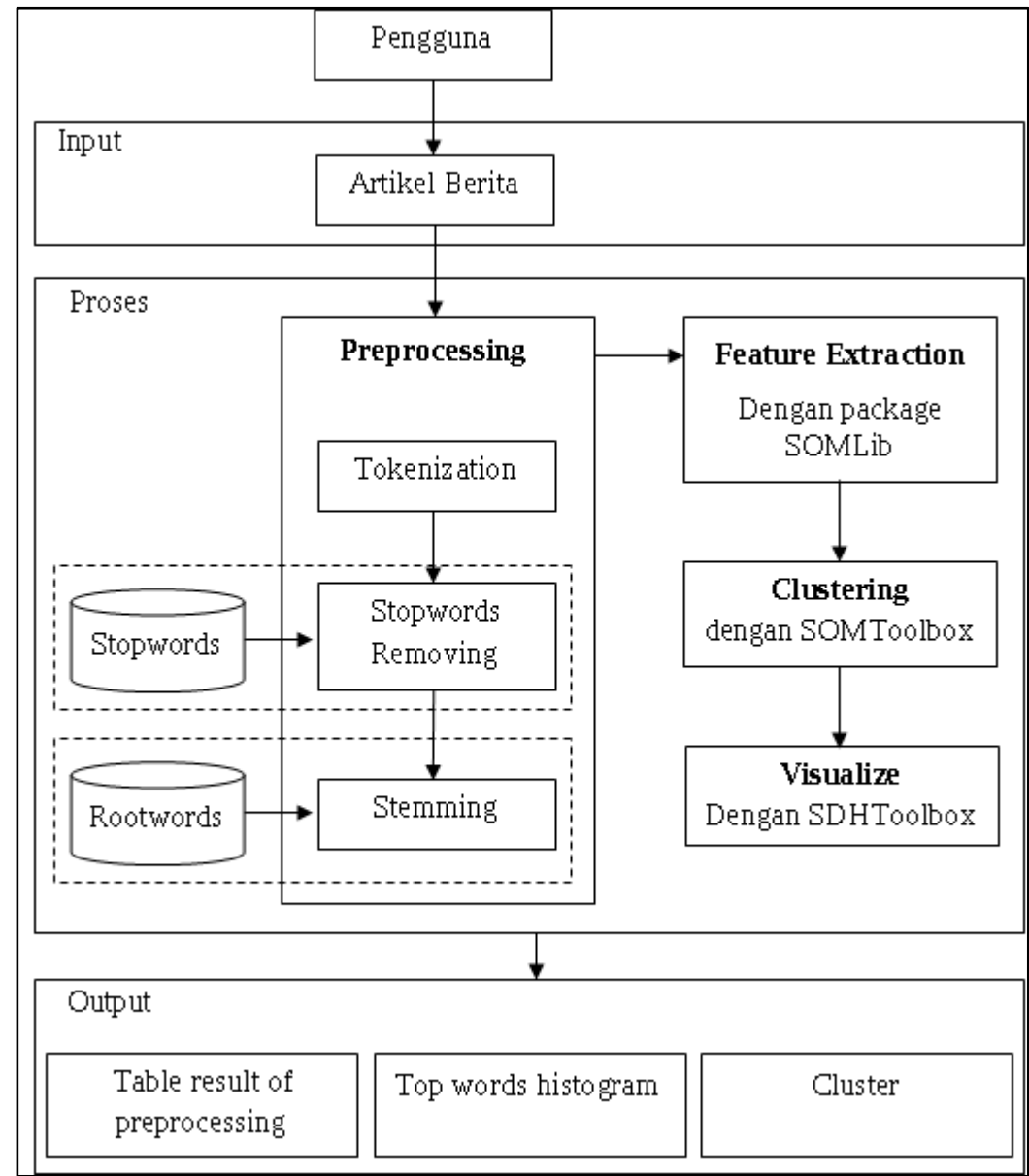

Gambar 1 Arsitektur sistem

\subsection{Implementasi}

Implementasi sistem ini merupakan hasil akhir dari rancangan antarmuka utama untuk pengguna. Antarmuka utama untuk pengguna ini berisi seluruh kegiatan yang dapat dilakukan pengguna untuk membentuk cluster. Antarmuka yang telah dibuat ini mempunyai empat buah menu yaitu menu pages, menu table, menu data statistics dan menu about seperti terlihat pada implementasi tampilan process pada Gambar 3. Antarmuka utama untuk pengguna mempunyai 2 form isian yang pertama untuk preprocessing dan feature extraction. Form isian kedua untuk clustering dan visualize.

Preprocessing diimplementasikan dengan membuat kode sendiri dari tokenization, stopwords removing dan stemming. Implementasi tokenization intinya dibuat untuk memisahkan deretan kata di dalam kalimat, paragraf atau halaman menjadi token. Implementasi stopwords removing pada intinya dibuat untuk mencocokan kata hasil dari proses tokenization dengan kata-kata yang terdapat dalam kamus stopwords yang telah dibuat, jika terdapat kata yang sama maka kata itu akan dihapus. Implementasi stemming dibuat untuk membentuk kata dasar dengan algoritma Nazief dan Adriani.

Feature extraction diimplementasikan dengan menggunakan package SOMLib. Class yang digunakan pada package SOMLib dapat melakuakan proses ekstraksi fitur pada artikel berita yang tersimpan dalam satu direktori. Class yang dipakai pada package SOMLib adalah class wordsexc, templatevectorexc, reducerexc dan extractorexc. Class tersebut akan dipanggil dengan menggunakan perintah cmd pada matlab.

Proses clustering diimplementasikan dengan memanfaatkan SOMToolbox dengan metode Self Organizing Map. Gambar 2 adalah struktur dari data yang dipakai sebagai masukan oleh SOM. Oleh sebab itu data yang akan dikelompokan harus diubah ke format matrik dengan 
fungsi InputSOM bertujuan untuk membaca bobot hasil proses extractorexc. Pada Gambar 3 menampilkan antarmuka utama untuk pengguna.

\begin{tabular}{|c|c|}
\hline ab type & 'som_data' \\
\hline$\boxplus$ data & $\langle 570 \times 2357$ double $\rangle$ \\
\hline [0] labels & $\langle 570 \times 1$ cell $\rangle$ \\
\hline $\begin{array}{ll}\mathrm{ab} \text { name } \\
\text { a }\end{array}$ & 'News Structure' \\
\hline [3] comp_names & $<2357 \times 1$ cell $>$ \\
\hline [1] comp_norm & $\langle 2357 \times 1$ cell $\rangle$ \\
\hline 巴label_names & [ ] \\
\hline
\end{tabular}

Gambar 2 Struktur data SOMToolbox

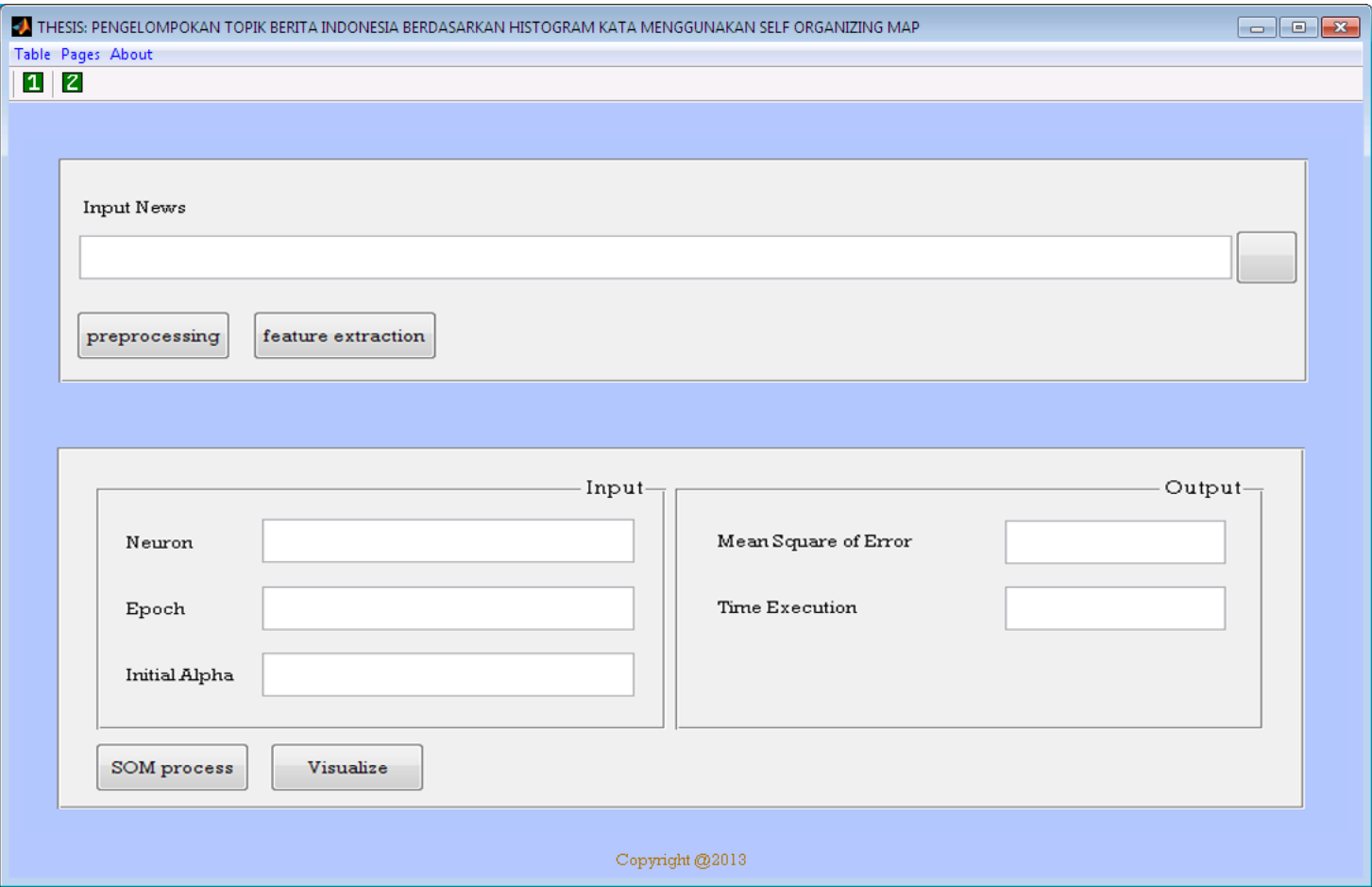

Gambar 3. Antarmuka utama untuk penguna

Proses visualize diimplementasikan dengan memanfaatkan SDHToolbox untuk mendapatkan model island dari cluster yang terbentuk. Implementasi visualize berfungsi untuk menghasilkan visualisasi hasil klusterisasi dalam bentuk island map. Ketika user menekan tombol SOM Visualize maka sistem akan menjalankan fungsi Smooth Data Histogram (SDH), berikut adalah fungsi dari SDH:

sdh_visualize(S, 'labels', sMap.labels, 'sofn', 0, 'type', continuous', 'grid', ' $\circ \bar{N}^{\prime}$ )

\section{HASIL DAN PEMBAHASAN}

Hasil yang diperoleh dari penelitian ini terbagi atas tahap-tahap proses yang dilakukan sistem. Pembahasan pertama dari hasil yang diperoleh pada preprocessing kata. Dari artikel dokumen yang diinputkkan sebanyak 570 file dimana file eko010102.txt mempunyai jumlah kata sebanyak 1267 pada tahap preprocessing sistem menghasilkan 1111 kata pada proses tokenization, 677 kata pada proses stopwords removing dan 677 kata dasar pada proses stemming. Hasil perbandingan banyaknya kata bisa dilihat pada perbandingan antar tabel. 
Tabel 1 Kata sebelum proses

\begin{tabular}{|r|l|l|l|}
\multicolumn{5}{|c|}{ Amount of Data 1267 wrords } \\
\hline & \multicolumn{1}{|c|}{2} & \multicolumn{1}{|c|}{3} \\
\hline 1 & \begin{tabular}{l|lll} 
Ekonomi \\
triliun,
\end{tabular} & terbakar \\
\hline 2 & Bisnis & di & di \\
\hline
\end{tabular}

Tabel 3 Kata proses stopwords

\begin{tabular}{|c|c|c|c|}
\hline & 1 & 2 & 3 \\
\hline 1 & ekonomi & babi & terus-terusan \\
\hline 2 & bisnis & emas & mendatangkan \\
\hline
\end{tabular}

Tabel 2 Kata proses tokenization

Amount of Data 1111 wrords
\begin{tabular}{|c|l|l|l|}
\hline & 1 & 2 & \multicolumn{2}{|c|}{3} \\
\hline 1 & ekonomi & lalu & ounce \\
\hline 2 & bisnis & triliun & pada \\
\hline
\end{tabular}

Tabel 4 Kata proses stemming

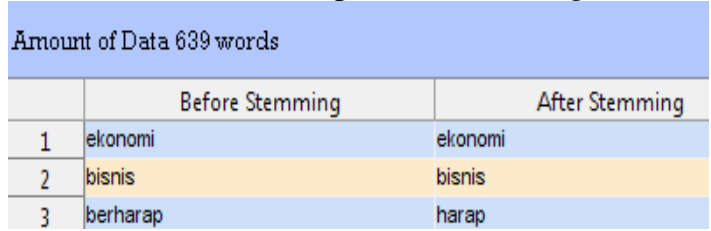

Terlihat pada perbandingan antar tabel kata pada file eko010102.txt mengalami pengurangan. Pada proses tokenization file berkurang sebanyak 156 kata, karena dalam proses ini dilakukan pembuangan karakter-karakter yang tidak diperlukan. Pada proses stopwords removing kata berkurang lagi sebanyak 434 kata, karena dalam proses ini ada pembuangan kata dari kamus stopwords. Pada proses stemming kata tetap tidak mengalami pengurangan namun jika dilihat dari tabel 4 kata mengalami peribahan bentuk menjadi kata dasar.

Pembahasan kedua diperoleh dari hasil ekstraksi ciri, dimana pada proses ini menggunakan package SOMLib. Ekstraksi ciri yang didapatkan berupa matriks dengan ukuran $\mathrm{n}$ x m dimensi. Gambar 4 menunjukan potongan hasil ekstraksi ciri pada proses ini.

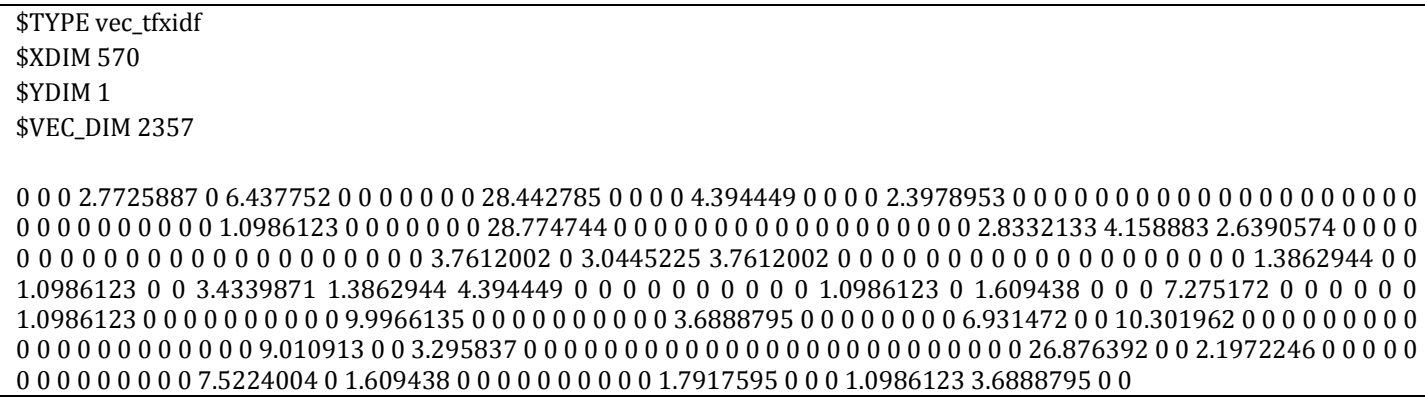

Gambar 4 Hasil feature extraction

Pembahasan ketiga diperoleh dari hasil clustering dengan menggunakan SOMToolbox dan SDHToolbox. Hasil cluster pada majalah Tempo tahun 2007 mempunyai 11 island, dimana island terbesar tidak memiliki mountain. Hasil cluster terbesar pada Gambar 5 didominasi dengan berita ekonomi dengan file terbanyak berjumlah 61 file yang berada pada 3 kotak membentuk satu cluster. Sedangkan cluster ke dua mempunyai 1 mountain dengan jumlah 41 file yang berisi berita ekonomi. Ada dua cluster yang sama besar dimana didalamnya terdapat satu mountain dengan jumlah 39 file dimana 1 cluster berisi berita menengani kesehatan dan 1 cluster berita tentang film.

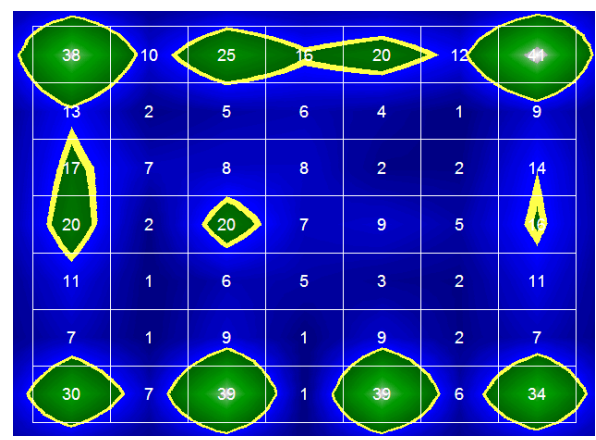

Gambar 5 Hasil cluster pada majalah Tempo tahun 2007 
Hasil cluster terbesar pada Gambar 6 mempunyai 37 file yang terletak dalam 2 kotak. Pada kotak pertama didominasi berita yang berisikan kriminal dan pada kotak kedua didominasi berita yang berisikan teknologi, karena kedua kotak ini merupakan satu cluster maka kecenderungan berita didalamnya mempunyai banyak kemiripan kata. Cluster terbesar kedua mempunya 33 file dimana isi berita didalamnya adalah berita kesehatan. Ada dua cluster terbesar ketiga dengan jumlah file 31 file berisi berita kesehatan dan 31 file berisi berita ekonomi.

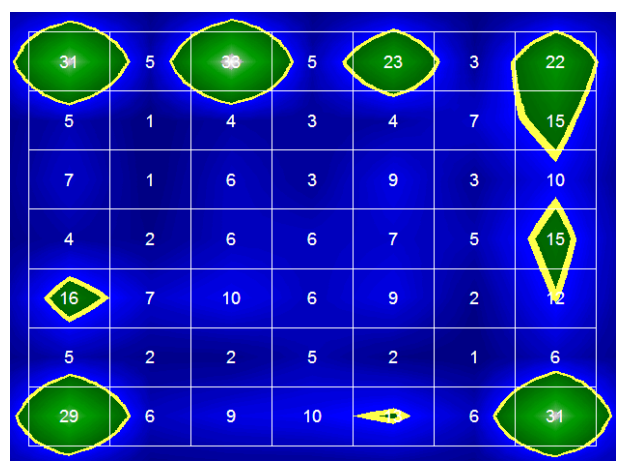

Gambar 6 Hasil cluster pada majalah Tempo tahun 2008

Hasil cluster terbesar pada Gambar 7 file Tempo tahun 2009 ada 7 island yang terbentuk pada proses clustering ini, dimana island terbesar mempunyai 39 file dan island terkecil mempunyai 17 file. Pada Gambar 7 terlihat ada dua buah cluster yang mempunyai jumlah berita yang sama banyak yaitu 39 file, dimana kedua cluster ini mempunyai kesamaan isi berita yaitu berita mengenai ekonomi. Perbedaan kedua cluster ini terletak pada mountain yang satu cluster untuk mempunyai mountain sedangkan cluster dari dua kotak tidak terdapat mountain. Cluster terbesar kedua berisi berita ekonomi dengan jumlah file sebanyak 33 file. Sedangkan cluster terbesar ke tiga berjumlah 32 file dengan isi berita yang mengulas mengenai kesehatan

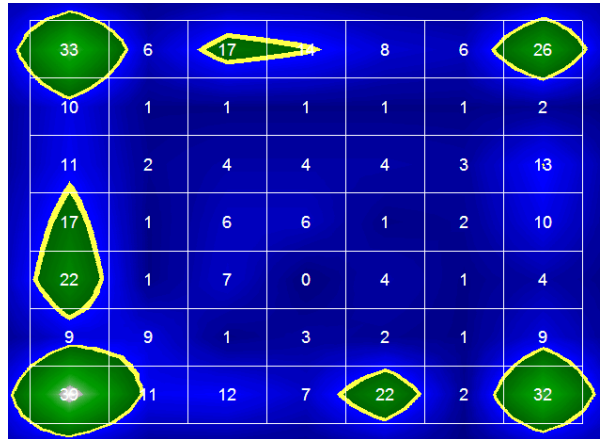

Gambar 7 Hasil cluster pada majalah Tempo tahun 2009

Dari tahun 2007 sampai dengan tahun 2009 hasil proses clustering memiliki kecenderungan yang berbeda, pada tahun 2007 mempunyai kecenderungan berita ekonomi, sedangkan pada tahun 2008 kecenderungan berita kriminal dan teknologi, yang terakhir uji coba data teks pada tahun 2009 kembali lagi mempunyai kecenderungan berita ekonomi.

Pembahasan keempat diperoleh dari hasil dari proses wordsexc dapat digunakan sebagai analisa data statistik untuk kemunculan kata terbanyak tiap jenis artikel berita (top 10 words). Gambar 8 adalah salah satu gambar yang memberikan keterangan data statistik dari 10 kata yang muncul dengan nama artikel eko10102 tahun 2007. Dari isi artikel eko10102 kata-kata yang banyak muncul adalah reksadana dengan frekuensi kemunculan sebanyak 20 kali. Tentunya data statistik 10 kata yang sering muncul akan berbeda dalam tiap artikelnya karena kemungkinan isi dari artikel beritanya berbeda. Dari kata-kata yang sering muncul ini dapat dibandingkan untuk mengetahui kemiripan isi dari tiap jenis artikel berita.

IJCCS Vol. 8, No. 1, January 2014: $101-110$ 


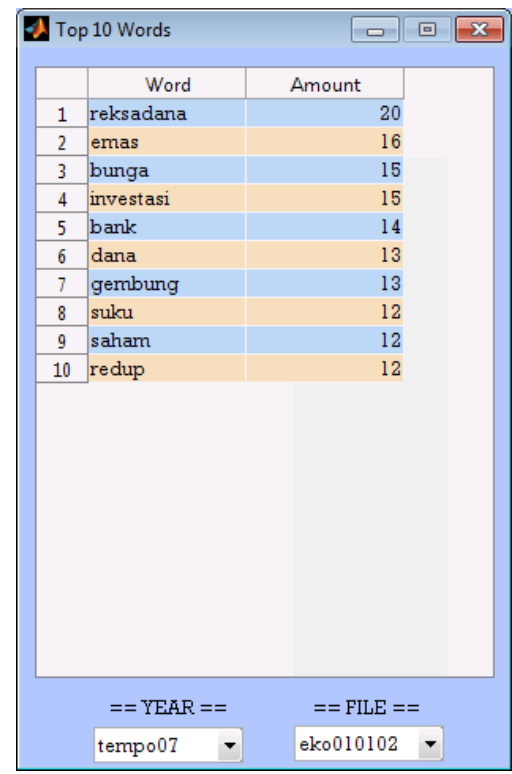

Gambar 8 Informasi top 10 words yang muncul dari artikel eko10102 tahun 2007

\section{KESIMPULAN}

1. Dari tahun 2007 sampai dengan tahun 2009 hasil proses clustering memiliki kecenderungan yang berbeda, pada tahun 2007 mempunyai kecenderungan berita ekonomi, sedangkan pada tahun 2008 kecenderungan berita kriminal dan teknologi, yang terakhir uji coba data teks pada tahun 2009 kembali lagi mempunyai kecenderungan berita ekonomi.

2. Hasil pulau dari data dengan Smooted Data Histogram (SDH) sangat bergantung pada nilai atribut 'spread' pada SDH.

3. Sistem dapat menampilkan hasil clustering dengan algoritma Self Organizing Map dan menampilkan visualisasi dengan moothed data histograms berupa island map dari artikel berita pada majalah Tempo yang telah diproses.

4. Sistem dapat menampilkan koleksi dokumen dari lima kategori berita yang ada pada tiap tahunnya, selain itu sistem ini mampu menampilkan banyaknya kata yang sering muncul pada tiap artikel berita (top 10 words).

\section{SARAN}

1. Perlu menambahkan idiom atau frase karena dapat memperbaiki performansi cluster, karena tokenisasi pada sistem ini tidak memperhatikan bentuk idiom atau frasa.

2. Feature extraction yang digunakan dalam sistem ini didasarkan pada histogram kata, yang mempunyai banyak kelemahan karena seluruh kategori berita didasarkan pada banyaknya kata yang sama. Jadi bisa dicoba untuk feature extraction yang lain.

3. Artikel yang bisa diproses dalam sistem ini hanya berupa file tipe .txt, untuk itu perlu dikembangkan penelitian yang bisa menghendel lebih banyak tipe file seperti, html, doc, pdf dan lain sebagainya.

4. Perlu dibuat database untuk pengembangan sistem yang lebih lanjut agar data dapat terdistribusi dengan baik. 


\section{UCAPAN TERIMA KASIH}

Penulis mengucapkan terima kasih kepada Instituto Proffisional de Canossa yang telah memberi dukungan finansial terhadap penelitian ini.

\section{DAFTAR PUSTAKA}

[1]. Wibisono Y., dan Khodra, M. L., 2005, Clustering Berita Berbahasa Indonesia, Jurnal FPMIPA UPI dan KK Informatika ITB, Bandung.

[2]. Ramadan, R., 2007, Penerapan Pohon Untuk Klasifikasi Dokumen Teks Berbahasa Inggris, Seminar Nasional, Bandung.

[3]. Langgeni, D. P., Baizal A., dan Firdaus, Y., 2010, Clustering Artikel Berita Berbahasa Indonesia Menggunakan Unsupervised Feature Selection, Seminar Nasional Informatika, Yogyakarta.

[4]. Anggraeni, D., 2008, Klasifikasi Topik Menggunakan Metode Naive Bayes dan Maximum Entropi pada Artikel Media Masa dan Abstrak Tulisan, Skripsi, Program Ilmu Komputer, Universitas Indonesia, Depok.

[5]. Kohonen, T., 2000, Self-Organizing Maps of Massive Document Collections, IEEE-INNSENNS International Joint Conference on Neural Networks, Finland.

[6]. Vuori, V., 2002 Clustering Writing Styles with a Self-Organizing Map, IEEE Eighth International Workshop on Frontiers in Handwriting Recognition, Finland.

[7]. Perelomov, I., Azcarraga, A.P., Tan, J., dan Chua, T.S., 2002, Using Structured SelfOrganizing Maps in News Integration Websites, School of Computing, National University of Singapore, Singapore.

[8]. Bação, F.,dan Lobo, V., 2010, Introduction to Kohonen's Self-Organizing Maps, Instituto Superior de Estatistica E Gestao de Informacao, Universidade Nova de Lisboa, Portugal.

[9]. Siang, J. J., 2009, Jaringan Saraf Tiruan dan Pemrogramannya Menggunakan Matlab, Andi Offset, Yogyakarta. 